\title{
Roofer Dies After Gust of Wind Knocks Him And A Co-Worker Off Roof
}

\section{Incident Number: 13KY059}

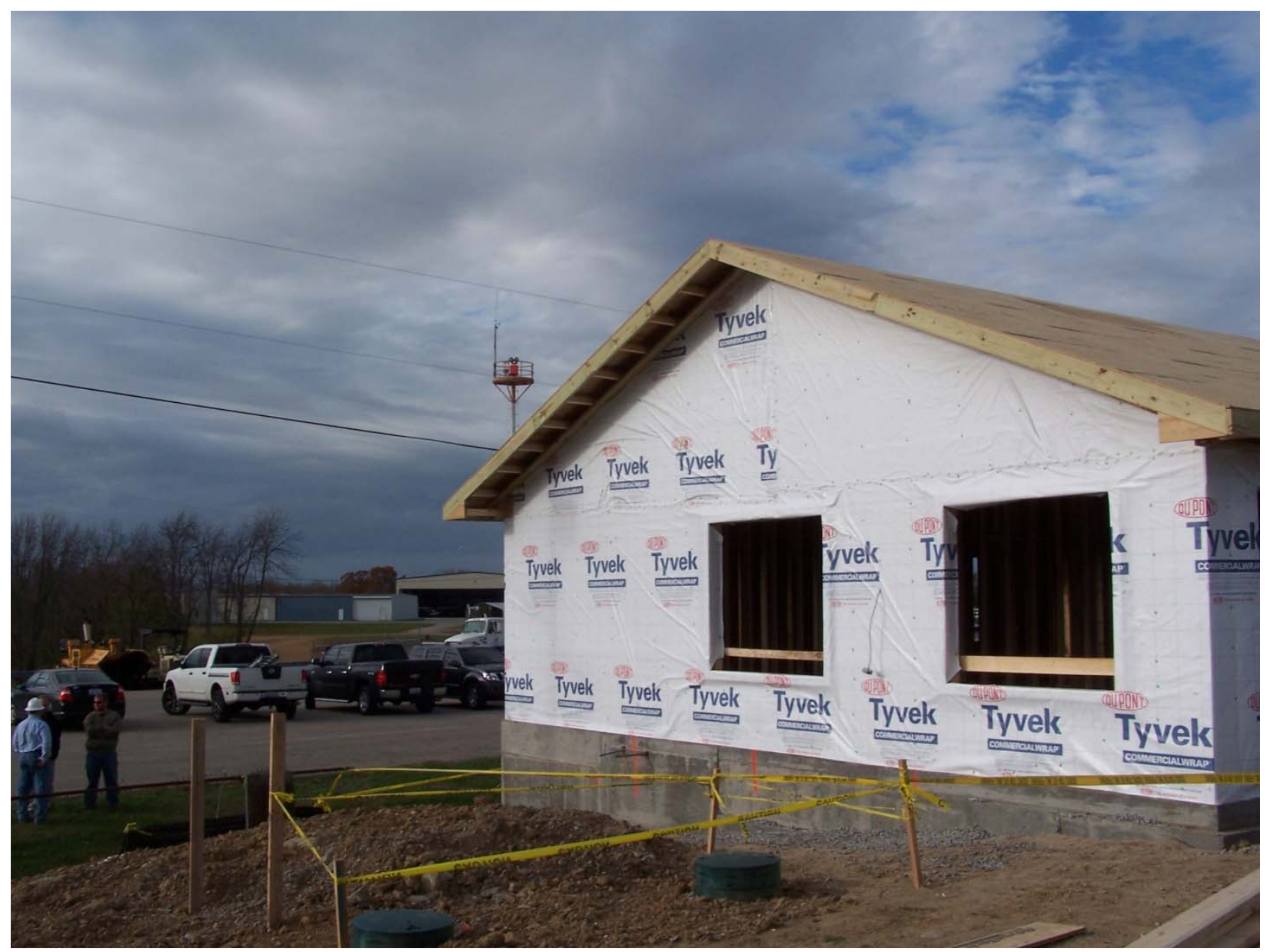

The fall took place from this structure. Photograph property of KY FACE Program

Kentucky Fatality Assessment and

Control Evaluation Program

Kentucky Injury Prevention and

Research Center

333 Waller Avenue Suite 242

Lexington, Kentucky 40504

Phone 859-323-3981 Fax 859-257-3909

www.kiprc.uky.edu

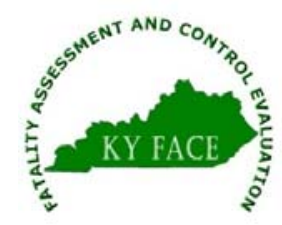




\section{Kentucky Fatality Assessment and Control Evaluation (FACE) Program Incident Number: 13KY059 \\ Release Date: Subject: Roofer Dies After Gust of Wind Knocks Him And Co-worker off Roof}

\section{SUMMARY:}

Around 11:00 a.m. on a windy fall day, a 73-year-old roofer and a roofing coworker arrived at the commercial construction site to roof a newly constructed building. The two roofers climbed an extension ladder to access the roof to determine where they were going to place their anchors to tie off. While reviewing the backside of the commercial structure, a gust of wind around 33 m.p.h. made the two roofers lose their balance and fall from the roof. The 73-year-old roofer landed first and the second roofer landed on top of him. Both men fell 15 feet and 6 inches and landed on a sloped grassy area.

To prevent future occurrences of similar incidents, the following recommendations have been made:

Recommendation No. 1: Employers should not allow their roofers to access roofing areas in times of windy, wet, or icy or conditions to prevent falls.

Recommendation No. 2: A roofer should use a personal fall protection system during all phases of a roofing job.

Recommendation No. 3: Employers should have a written fall protection program in place.

Recommendation No. 4: Employers should fully plan their fall protection system before it is used.

\section{Background}

The roofer was a part-time employee for the past five years. He had been a brick mason and was still employed as a part-time farmer who helped the family owned business as he was needed. The roofing company has been in business since 2006 and employs six workers, two of them are roofers. The company has a worker safety program in place and had trained all their employees on working safely. However, the training wasn't specific to fall protection or documented. There was no written fall protection plan but there was a competent person assigned and trained at the time of the incident.

On the day of the incident, the temperature ranged from 60-71 degrees Fahrenheit with no precipitation. The wind was blowing 18 to $20 \mathrm{mph}$ with gusts up to $33 \mathrm{mph}$. 


\section{Investigation}

The Kentucky Fatality Assessment and Control Evaluation Program was notified of by Kentucky Occupational Safety and Health an occupational fatality involving a fall from a roof. A site visit was made the day of the incident and photographs were taken; employees and witnesses interviewed.

Around 11:00 a.m. on a windy fall day, a 73-year-old roofer and roofing coworker arrived at the commercial construction site to roof a newly constructed building. The two roofers climbed the extension ladder to access the roof of the one story commercial building, to decide where they were going to place their anchors to tie off. They had not yet put on their personal fall protection gear. While reviewing the backside of the commercial structure, a gust of wind around 33 m.p.h. made the two roofers lose their balance and fall from the roof. At 11:09 a.m., the 73-year-old roofer landed first and the second roofer landed on top of him. Both roofers fell 15 feet 6 inches and landed on a sloped grassy area next to the commercial building.

Roofer \#2 stated that he heard roofer \#1 yell, “I’m falling.” Right after roofer \#2 heard roofer \#1 yell, roofer \#2 knew he was falling as well due to the wind gust and landed on top of roofer \#1.Roofer \#2 said that they were both looking to see where they were going to install the tie-off anchors and as he turned, a gust of wind came through causing them both to lose their balance and fall 15 feet 6 inches to the ground below. Roofer \#2 was very upset. Roofer \#2 was related to the roofer \#1, who was killed. Roofer \#2 said that everything happened so fast and that was all he could remember about the fatal incident.

Another sub-contractor, a supervisor for a different company on the jobsite immediately began CPR because Roofer \#1 was unresponsive. A call was placed to 911 at 11:14a.m. EMS arrived at 11:25 a.m. and took over. Roofer \#1 did not have a pulse and was not breathing. Roofer \#1 was transported to the nearest local hospital and was pronounced dead upon arrival at the hospital, at 11:50 a.m.

The roofer's body was sent to the state medical examiner's office for autopsy. The toxicology report was negative for substance abuse.

\section{Cause of Death}

The cause of death was blunt force injuries of the head and neck, due to fall.

\section{Recommendations and Discussions:}


Recommendation No. 1: Employers should not allow their roofers to access roofing areas in times of windy, wet, or icy conditions.

The weather was the major contributor to the fatal incident since the wind gusts were up to 33 mph and the construction zone was in a flat area. Employers should never allow their roofers to get on the roof during windy situations, wet or iced areas due to possible slips and falls. Employers should adapt to the OSHA standards for scaffolding use 1926.451 (f)(12) that states work on or from scaffolds is prohibited during storms or high winds unless a competent person has determined that is safe for employees to be on the scaffold and those employees are protected by a personal fall arrest system or wind screens. Wind screens shall not be used unless the scaffold is secured against the anticipated wind forces imposed. This same standard should be applied to roofers as well.

\section{Recommendation No. 2: A roofer should use a personal fall protection system during all phases of a roofing job.}

If the roofers had been wearing personal fall protection gear they could have placed their first anchor at the peak of the roof with a minimum of 6 feet from the edge and tied off immediately possibly saving them from the gust of wind that caused them to lose their balance and fall. It is unclear how much impact having one roofer land on the other roofer played into the fatal fall. It is not known if roofer \#1 would have survived if this had not been a factor. However, it did add to the force of the trauma. Only one roofer should access the roof to install anchors limiting the exposure.

\section{Recommendation No 3 Employers should have a written fall protection program in place.}

OSHA standard 1926.503 states that an employer shall assure that each employee has been trained as necessary, by a competent person qualified in the following areas: the nature of fall hazards in the work area; the correct procedures for erecting , maintaining, disassembling, and inspecting the fall protection systems to be used: the use and operation of guardrail systems, personal fall arrest systems, safety net systems, warning line systems, safety monitoring systems, controlled access zones, and other protection to be used; the role of each employee in the safety monitoring system when this system issued; the limitations on the use of mechanical equipment during the performance of roofing work on low-sloped roof; the correct procedures for handling and storage of equipment and materials and the erection of overhead protection; and the role of employees in fall protection plans. Training must keep a written certification record containing the name or the employee trained, the dates of training and the signature of the person who conducted the training.

Recommendation No. 4 Employers should fully plan their fall protection system before it is used. 
According to the Construction Industry OSHA standard 1926.503 under fall protection, related to tie off considerations, one of the most important aspects of personal fall protection systems is to fully plan the system before it is put into use. The amount of time your employees are at risk is therefore eliminated.

Keywords

Construction

Roofing

Fall protection

\section{References}

CCH safety professional series OSHA Standards for the Construction Industry fall protection 1926.500

http://www.OSHA.gov

http://www.download.bls.gov/

\section{Acknowledgements}

The Kentucky FACE program would like to thank the coroner's office, KYOSH inspectors and KYOSH Safety Supervisor Shannon Lancaster, and the company for their assistance with this report.

The Kentucky Fatality Assessment \& Control Evaluation Program (FACE) is funded by grant 2U60OH008483-09 from the Centers for Disease Control and Prevention and the National Institute for Occupational Safety and Health. The purpose of FACE is to aid in the research and prevention of occupational fatalities by evaluating events leading to, during, and after a work related fatality. Recommendations are made to help employers and employees have a safer work environment. For more information about FACE and KIPRC, please visit our website: www.kiprc.uky.edu 


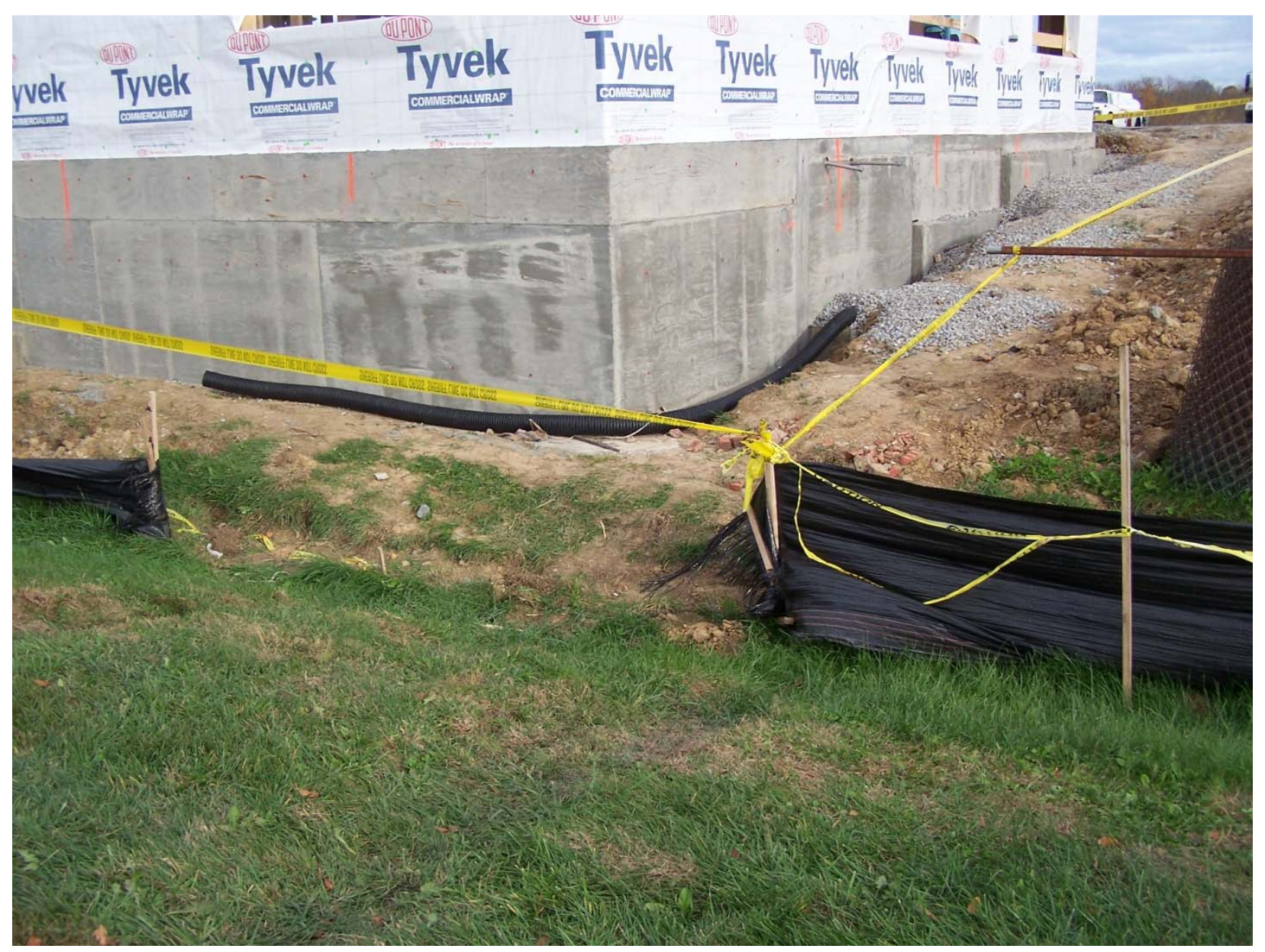

Area of impact where employees landed from fall. Photograph property of KY FACE Program 